\title{
ISOLASI JAMUR ENDOFIT DAUN JAHE MERAH (Zingiber officinale)
}

\author{
Nilam Cahaya*, Arsyik Ibrahim, Adam M. Ramadhan, Rolan Rusli \\ Laboratorium Penelitian dan Pengembangan "FARMAKA TROPIS" Fakultas Farmasi \\ Universitas Mulawarman, Samarinda, Kalimantan Timur \\ *email: cahayanilam48@gmail.com
}

\begin{abstract}
ABSTRAK
Jamur endofit adalah jamur yang terdapat dalam sistem jaringan tumbuhan. Jamur endofit dapat diisolasi dari akar, batang dan daun tumbuhan. Penelitian ini bertujuan mengisolasi jamur endofit dari daun jahe merah (Zingiber officinale) menggunakan medium Potato Dextrose Agar Chloramphenicol (PDAC), Yeast Extract Agar Chloramphenicol (YEAC), dan Malt Extract Agar Chloramphenicol (MEAC). Setelah isolat jamur endofit diperoleh dan dimurnikan, lalu dilakukan karakterisasi untuk mendapatkan profil isolat jamur endofit dengan metode makroskopik dan mikroskopik. Hasil penelitian adalah diperoleh tiga isolat jamur endofit yang tumbuh pada daun jahe merah. Tiga isolat jamur endofit yang diperoleh memiliki karakteristik berwarna hijau kehitaman 1, hitam dan hijau kehitaman 2.
\end{abstract}

Kata kunci: Jahe merah (Zingiber officinale), Jamur endofit, Isolasi

\section{ABSTRACT}

Endophytic fungi is a fungi that is found in plant system. Endophytic fungi can be isolated from root, rod, and leaf of plant. Endophytic fungi was isolated from leaf of red ginger (Zingiber officinale) using medium of Potato Dextrose Agar Chloramphenicol (PDAC), Yeast Extract Agar Chloramphenicol (YEAC), and Malt Extract Agar Chloramphenicol $(M E A C)$. After endophytic fungi isolates obtained and purified, and then in the characterization of isolates to obtain the profile of endophytic fungi isolates with macroscopic and microscopic methods. The result of this research were obtain three isolates of endophytic fungi. Characteristic of three isolated endophytic fungi is blackish green 1, black and blackish green 2.

Keywords : Red ginger (Zingiber officinale), Endophytic fungi, Isolation

\section{PENDAHULUAN}

Jahe memiliki efek farmakologis yang berkhasiat sebagai obat dan mampu memperkuat khasiat obat yang dicampurkannya. Dari ketiga jenis jahe yang ada, jahe merah yang lebih banyak digunakan sebagai obat, karena kandungan minyak atsiri dan oleoresinnya paling tinggi dibandingkan dengan jenis jahe yang lain (Lantera, 2005). Hasil penelitian menunjukkan bahwa bahan aktif jahe (gingerol) mampu menghambat pertumbuhan bakteri (Katno, 2008).

Jamur endofit adalah jamur yang hidup di dalam jaringan tanaman (pada xylem dan phloem), daun, akar, batang dan batang pada periode tertentu dan mampu hidup dengan membentuk koloni dalam jaringan tanaman tanpa membahayakan inangnya. Telah didokumentasikan bahwa jamur endofit dapat memberikan aktivitas yang menguntungkan bagi tanaman inangnya, seperti mendukung pertumbuhan, kesehatan tanaman inang, 
berkontribusi dalam pertahanan tanaman inang terhadap patogen seperti herbivora, ataupun stres terhadap lingkungan, memainkan fungsi ekologi yang terpenting dalam suksesi tanaman, dan merupakan tempat penyimpanan metabolit sekunder yang beberapa diantaranya memiliki aktivitas biologi yang menguntungkan (Agustra, 2009).

\section{METODE PENELITIAN}

\section{Bahan}

Daun jahe merah (Zingiber officinale), alkohol 70\%, $\mathrm{NaOCl} 5,25 \%$, medium Potato Dextrose Agar/ PDA, medium Yeast Extract Agar/ YEA, medium Malt Extract Agar/MEA, kloramfenikol.

\section{Peralatan}

Peralatan yang digunakan dalam penelitian ini adalah timbangan analitik, autoklaf, inkubator, cawan petri, erlenmeyer, gelas kimia, spoit injeksi, hot plate, bisturi, Laminar Air Flow, mikroskop kamera dan alat penunjang lainnya.

\section{Prosedur Kerja}

\section{a. Isolasi Jamur Endofit}

Isolasi jamur endofit dari tanaman yang berbeda ataupun dari bagian tanaman yang berbeda tetapi dari satu tumbuhan inang memiliki jenis isolat jamur yang berbeda Teknik isolasi jamur endofit ini dilakukan dengan metode tanam langsung. Selama pengerjaan isolasi dilakukan di dalam LAF (Laminar Air Flow) dalam kondisi steril. Sampel daun jahe merah dicuci dengan air mengalir terlebih dahulu. Selanjutnya dilakukan sterilisasi permukaan sampel dengan cara direndam sampel dalam alkohol 70\% selama 1 menit, kemudian direndam dalam $\mathrm{NaOCl} 5,25 \%$ selama 3 menit dan direndam kembali dalam alkohol 70\% selama 30 detik. Proses sterilisasi permukaan untuk dapat menjamin sterilitas permukaan sampel dari kontaminasi organisme. Jaringan daun dibuka dengan cara dilakukan pengikisan permukan daun menggunakan pisau steril, kemudian dipotong dengan ukuran \pm $1 \times 1 \mathrm{~cm}$. Masing-masing potongan sampel diletakkan pada permukaan medium PDAC (Potato Dextrose Agar Chloramphenicol), medium YEAC (Yeast Extract Agar Chloramphenicol) dan medium MEAC (Malt Extract Agar Chloramphenicol) yang telah memadat dengan posisi bagian jaringan daun menempel pada medium, medium yang ditambahkan dengan kloramfenikol dilakukan untuk menekan pertumbuhan bakteri yang kemungkinan ikut tumbuh saat isolasi, dalam satu cawan petri berisi 6 potongan sampel. Diinkubasi selama 7-14 hari pada suhu $25^{\circ} \mathrm{C}$.

\section{b. Pemurnian Jamur Endofit}

Pemurnian dilakukan untuk memisahkan koloni jamur endofit hingga diperoleh isolat jamur endofit. Koloni jamur yang tumbuh di sekeliling sampel daun jahe merah dimurnikan berdasarkan morfologi makroskopik yang dapat diamati dari warna serta pertumbuhan koloni jamur. Diambil jamur endofit menggunakan ose, kemudian diinokulasikan dalam medium PDAC, YEAC dan MEAC. Diinkubasi selama 5-7 hari pada suhu $25{ }^{\circ} \mathrm{C}$, jika pada saat pengamatan ditemukan pertumbuhan koloni yang berbeda secara makroskopis maka dipisahkan kembali hingga diperoleh isolat murni.

\section{c. Karakterisasi Isolat Jamur Endofit}

Karakterisasi isolat jamur endofit dengan melakukan pengamatan ciri-ciri makroskopik dan mikroskopik. Karakterisasi secara makroskopik ini dilakukan dengan pengamatan isolat jamur endofit yang telah murni meliputi warna koloni, ukuran koloni, 
bentuk koloni, elevasi dan tepi koloni. Karakterisasi secara mikroskopik ini dilakukan pengamatan menggunakan preparat isolat jamur endofit melalui mikroskop. Terdapat dua jenis metode mikroskopik yaitu metode mikroskopik langsung dan mikroskopik tidak langsung. Metode mikroskopik langsung dilakukan dengan meneteskan methylen blue yang telah diinokulasikan isolat jamur endofit dan diamati menggunakan mikroskop. Sedangkan metode mikroskopik tidak langsung dilakukan dengan cara diinokulasikan isolat jamur endofit di atas medium PDA, YEA dan MEA yang ada di object glass dan dibuat dalam kondisi lembab dengan gliserin yang ditetesi pada kertas saring sebagai pelapis cawan petri, kemudian diinkubasi selama 3-5 hari pada suhu $25^{\circ} \mathrm{C}$, selanjutnya diamati menggunakan mikroskop.

\section{HASIL DAN PEMBAHASAN}

\section{a. Isolasi Jamur Endofit}

Hasil dari isolasi jamur endofit pada ketiga replikasi setelah dilakukan pengamatan selama 2 minggu dapat dilihat pada gambar 1.

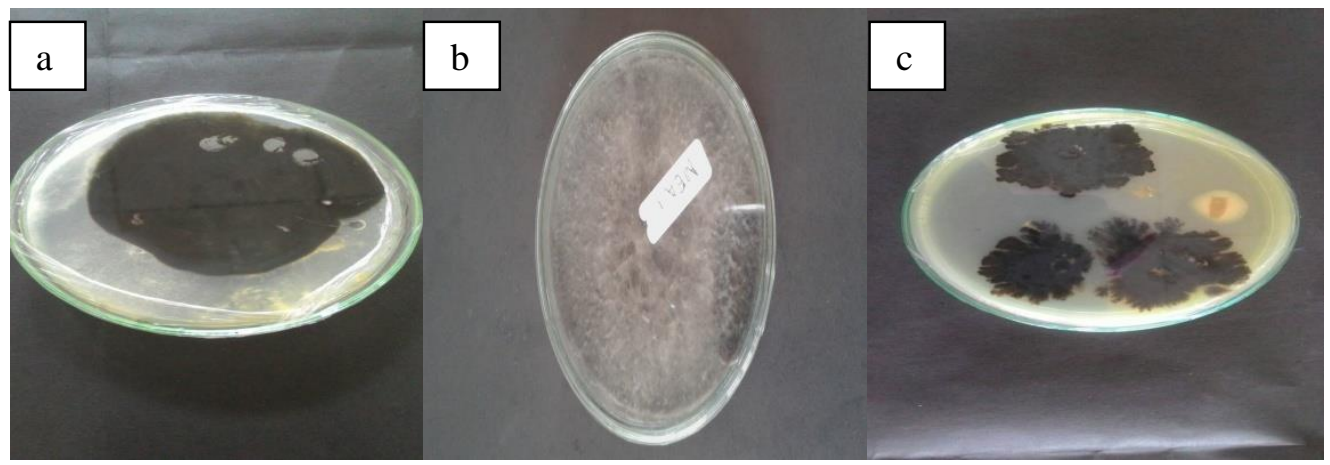

Gambar 1. Jamur Endofit dari daun jahe merah (Zingiber officinale) setelah inkubasi selama 2 minggu, (a) Replikasi Pertama, (b) Replikasi kedua, (c) Replikasi ketiga

Jamur endofit yang tumbuh di sekeliling daun jahe merah dimurnikan hingga memperoleh isolat jamur endofit. Pemisahan ini berdasarkan warna dan pola pertumbuhan koloni jamur dan ditumbuhkan kembali dalam medium PDAC, YEAC dan MEAC yang baru. Berdasarkan Gambar 1, hasil isolat pada replikasi pertama dan ketiga secara makroskopik dalam satu cawan hanya terdapat satu jenis jamur endofit yang tumbuh dalam satu cawan. Jamur endofit yang tumbuh pada replikasi pertama dan ketiga memiliki warna yang sama yaitu berwarna hijau kehitaman, tetapi memiliki pola pertumbuhan yang berbeda sehingga dapat disimpulkan bahwa jamur endofit yang tumbuh pada replikasi pertama dan replikasi ketiga berbeda. Pada replikasi kedua berdasarkan pengamatan secara makroskopik dalam satu cawan terdapat jamur endofit yang memiliki warna hitam.

\section{b. Karakterisasi Isolat Jamur Endofit}

Isolat jamur endofit dari daun jahe merah yang telah murni selanjutnya dikarakterisasi untuk melihat ciri-ciri jamur secara makroskopik dan mikroskopik. Hasil isolasi jamur endofit dari daun jahe merah dapat dilihat pada Gambar 2.

Berdasarkan Gambar 2 dapat dilihat hasil isolasi jamur endofit dari daun jahe merah (Zingiber officinale) diperoleh tiga isolat jamur endofit yaitu isolat jamur endofit hijau kehitaman 1, isolat jamur endofit hitam dan isolat jamur endofit hijau kehitaman 2. 
Pengamatan makroskopik pada isolat jamur endofit hijau kehitaman 1 yang tumbuh pada medium PDA koloni berwarna gelap hijau kehitaman dan sebalik koloni juga berwarna hijau kehitaman. Ukuran dari isolat jamur endofit hijau kehitaman 1 ini ialah berukuran sedang. Dilihat dari atas berbentuk bulat dengan tepi halus. Hasil pengamatan mikroskopik isolat jamur endofit hijau kehitaman 1 memiliki konidiofor dan hifa. Pada isolat jamur endofit hitam yang tumbuh pada medium MEA koloni awalnya berwarna putih, lama-kelamaan bagian dasar koloni warna berubah menjadi hitam dan sebalik koloni berwarna hitam. Dilihat dari atas bentuk bulat, elevasi lebat dan dengan tepi halus. Hasil pengamatan mikroskopik isolat jamur endofit hitam memiliki hifa dan memiliki konidiofor. Pada isolat jamur endofit hijau kehitaman 2 yang tumbuh pada medium YEA koloni berwarna hijau kehitaman dan sebalik koloni juga berwarna hijau kehitaman. Dilihat dari atas bentuk menyebar tidak teratur, elevasi halus dan dengan tepi timbul bergelombang. Hasil pengamatan mikroskopik isolat jamur endofit hijau kehitaman 2 memiliki hifa dan memiliki konidiospora dengan bentuk bulat.

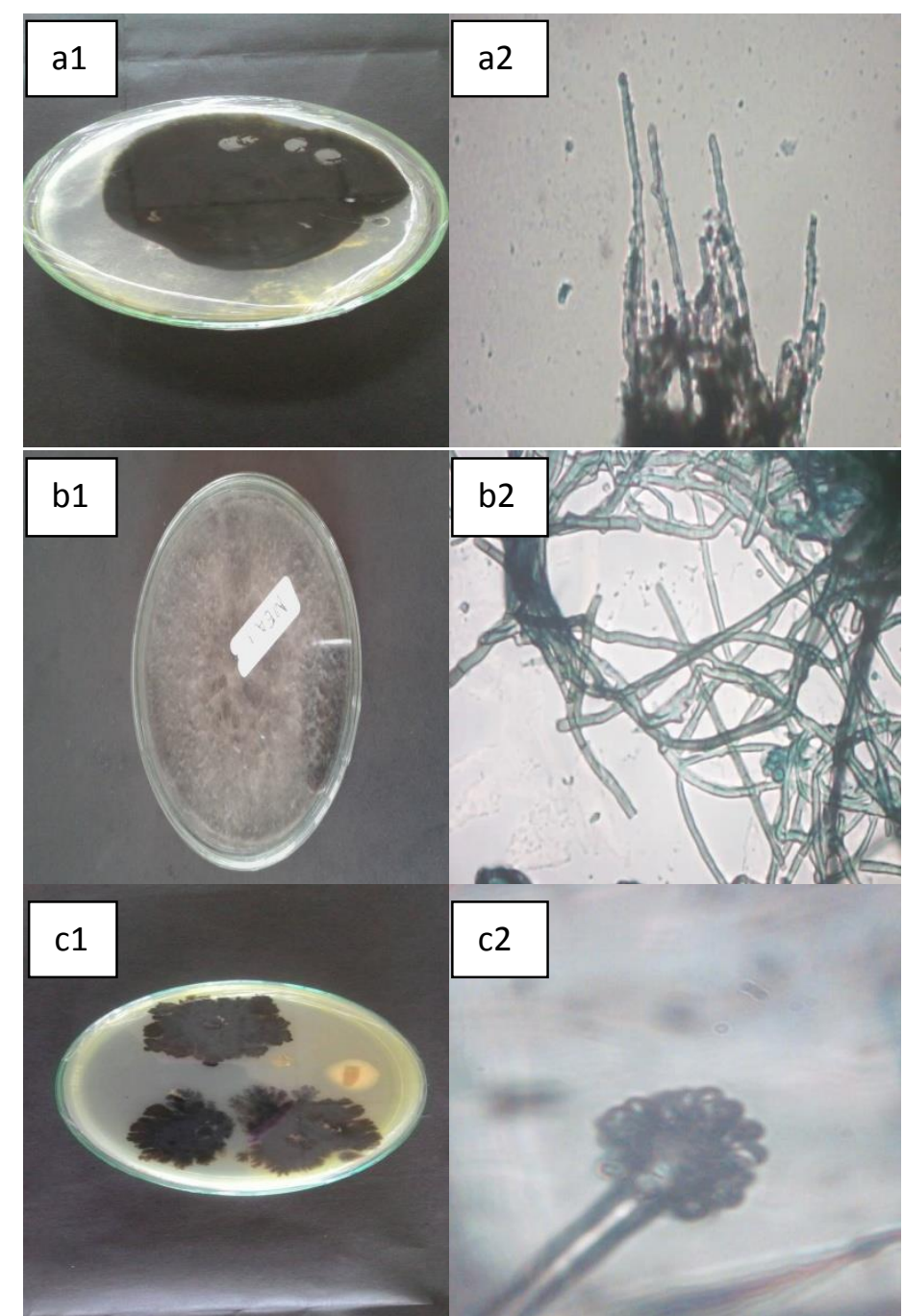

Gambar 2. Isolat Jamur Endofit daun jahe merah (Zingiber officinale). Diperoleh tiga isolat jamur endofit, yaitu (a1) Isolat Jamur Endofit Hijau Kehitaman 1, (a2) hasil pengamatan Mikroskopik Isolat Jamur Endofit Hijau Kehitaman 1, (b1) Isolat Jamur Endofit Hitam, (b2) hasil Pengamatan Mikroskopik Isolat Jamur Endofit Hitam, (c1) Isolat Jamur Endofit Hijau Kehitaman 2, dan (c2) hasil Pengamatan Mikroskopik Isolat Jamur Endofit Hijau Kehitaman 2 


\section{KESIMPULAN}

Hasil isolasi jamur endofit dari daun jahe merah (Zingiber officinale) diperoleh tiga isolat jamur endofit yaitu isolat jamur endofit hijau kehitaman 1, isolat jamur endofit hitam dan isolat jamur endofit hijau kehitaman 2.

\section{DAFTAR PUSTAKA}

Agustra, A. 2009. Biologi dan Kimia Jamur Endofit. Penerbit ITB : Bandung.

TIM Lentera, 2005. Khasiat dan Manfaat Jahe Merah si Rimpang Ajaib. Penerbit PT. Agromedia Pustaka : Jakarta.

Katno, Pramono S. 2008. Tingkat Manfaat dan Keamanan Tanaman Obat Tradisional. Fakultas Farmasi UGM : Yogyakarta.

Agustra, A. 2009. Biologi dan Kimia Jamur Endofit. Penerbit ITB : Bandung.

Aly, A.H., A. Debbab, and P. Proksch. 2011. Fungal Endophytes : Unique Plant Inhabitants with Great Promises. Appl Microbiol Biotechnol. 90 : 1829-1845

Djide, N.M. dan Sartini. 2008. Analisis Mikrobiologi Farmasi. Laboratorium Mikrobiologi Jurusan Farmasi UNHAS : Makassar.

Radji, M. 2005. Buku Ajar Mikrobiologi Panduan Mahasiswa Farmasi dan Kedokterran. EGC : Jakarta. 